\title{
TRENDY EKSPLORACJI ZJAWISKA OPORTUNIZMU W PUBLIKACJACH NAUKOWYCH
}

DOI: 10.33141/po.2020.01.04

\author{
Iwona Staniec
}

\section{Wprowadzenie}

$\mathbf{Z}$ definiowany przez O.E. Williamsona (1985, s. 122) oportunizm jako tendencja do podstępnego zachowania prowadzącego do wyraźnego etycznego naruszenia umowy o współpracy lub norm relacyjnych pozostaje jednym ze zjawisk budzących zainteresowanie badaczy. Jego postrzeganie od momentu zdefiniowania przez O.E. Williamsona (1985) ewoluowało. W literaturze (Luo, 2006; Kashyap i in., 2012; Heide i in., 2007; Kelly i in., 2018) podkreśla się, że $\mathrm{w}$ walce $\mathrm{z}$ oportunizmem istotne jest uczenie się poprzez monitorowanie, symetryczność informacji i bieżące obserwowanie intencji oraz możliwości każdej ze stron, jak również elastyczność każdej ze stron pozwalająca na bieżące rozwiązywanie problemów. Y. Luo (2006, s. 126) pokazuje wzrost kosztów informacji u firm, które dostrzegają to zagrożenie i monitorują zachowanie drugiej strony. Wskazuje również, że strach przed takim zachowaniem jest szkodliwy dla budowania zaufania i eskaluje konflikty między stronami, co osłabia podstawy współpracy. Zatem oportunizm zwiększa niepewność efektów współpracy, przeszkadza w rozwoju relacji lub wielokrotnym zaangażowaniu. Dodatkowo W. Czakon (2005, s. 12) zauważa, że zaangażowanie w relacje staje się mechanizmem zabezpieczającym przed oportunizmem. Współcześnie w kontekście teorii kosztów transakcyjnych zwraca się uwagę przede wszystkim na to, że w obniżeniu kosztów wynikających z zabezpieczania się wobec potencjalnego oportunizmu partnerów czy ich ograniczonej racjonalności pomagają relacje sieciowe i działalność przedsiębiorstwa w sieci (Ratajczak-Mrozek, Zieliński, 2013, s. 32-37).

Celem pracy jest identyfikacja trendów eksploracji zjawiska oportunizmu w publikacjach naukowych. Na jego podstawie starano się odpowiedzieć na następujące pytania badawcze:

1. Jakie są trendy eksploracji zjawiska oportunizmu?

2. Jakie są niszowe nurty badawcze w zakresie oportunizmu?

\section{Metoda badawcza}

W pracy zastosowano badania bibliometryczne ${ }^{1}$ rozumiane jako wykorzystanie analiz ilościowych i jakościowych do przeglądu publikacji pod względem liczebności i zawartości tematycznej. Obiektem prowadzonych badań są artykuły naukowe, a przedmiotem opisywane $\mathrm{w}$ nich postrzeganie oportunizmu oraz jego charaktery- styki. Badania przeprowadzono w dwóch etapach zgodnie z wytycznymi (Czakon, 2011, s. 58-59):

- pierwszy uwzględniający tylko badania ilościowe dotyczące wskazań liczbowych;

- drugi uwzględniający badania jakościowe związane z opisem stosowanych koncepcji, definicji, nurtów badawczych, charakterystyki badań.

W pierwszym etapie analiza bibliometryczna pozwoliła na analizę trendów szeregów czasowych, odzwierciadlających liczbę publikacji z wybranych obszarów oraz identyfikację przestrzenną badaczy prowadzących badania na określony temat. Ograniczone możliwości wykorzystywanej wyszukiwarki EBSCO Discovery Service (EDS) ${ }^{2}$ oraz brak dostępu do narzędzi analitycznych Big Data dla danych tekstowych ${ }^{3}$ spowodowały, że $\mathrm{w}$ drugim etapie zastosowano badania jakościowe otrzymanych treści polegające na stworzeniu klucza kategoryzacyjnego, będącego ustrukturyzowanym zbiorem kategorii tematycznych zawartych w artykułach. Za klucze kategoryzacyjne $\mathrm{w}$ analizie treści przyjęto: definicje oportunizmu, rodzaje oportunizmu, rodzaje i typy prac naukowych, podmioty i przedmioty badań, czynniki kontekstowe. $W$ drugim etapie badań ze względu na zastosowaną technikę konieczne było ograniczenie próby badawczej i dlatego wprowadzono dodatkowe kryteria selekcji wybranych prac dostępne $\mathrm{w}$ wyszukiwarce EDS. Wnioski $\mathrm{z}$ badań prowadzonych w taki sposób dotyczyć mogą tylko zbioru analizowanych tekstów postrzeganych jako całość (Czakon, 2011, s. 60). Ich wadą jest brak obiektywizmu, który może być jedynie postulatem, mającym podkreślić konieczność unikania wszelkiej arbitralności i subiektywizmu.

\section{Oportunizm w statystykach publikacji naukowych bazy EBSCO}

W ramach przeglądu literatury analizie poddano dane dotyczące publikacji zaindeksowanych w bazie EBSCO, wybierając w pierwszym etapie wszystkie dostępne bazy, np. Complementary Index, Business Source Ultimate, Academic Search Ultimate, eBook Index Social Sciences Citation Index, Scopus, Science Direct, Science Citation Index, Supplemental Index, JSTOR Journals, eBook Collection (EBSCOhost), BazEkon, a w drugim tylko bazę danych Business Source Ultimate. Do wyboru publikacji w dniu 10.01.2020 r. wykorzystano wyszukiwarkę 


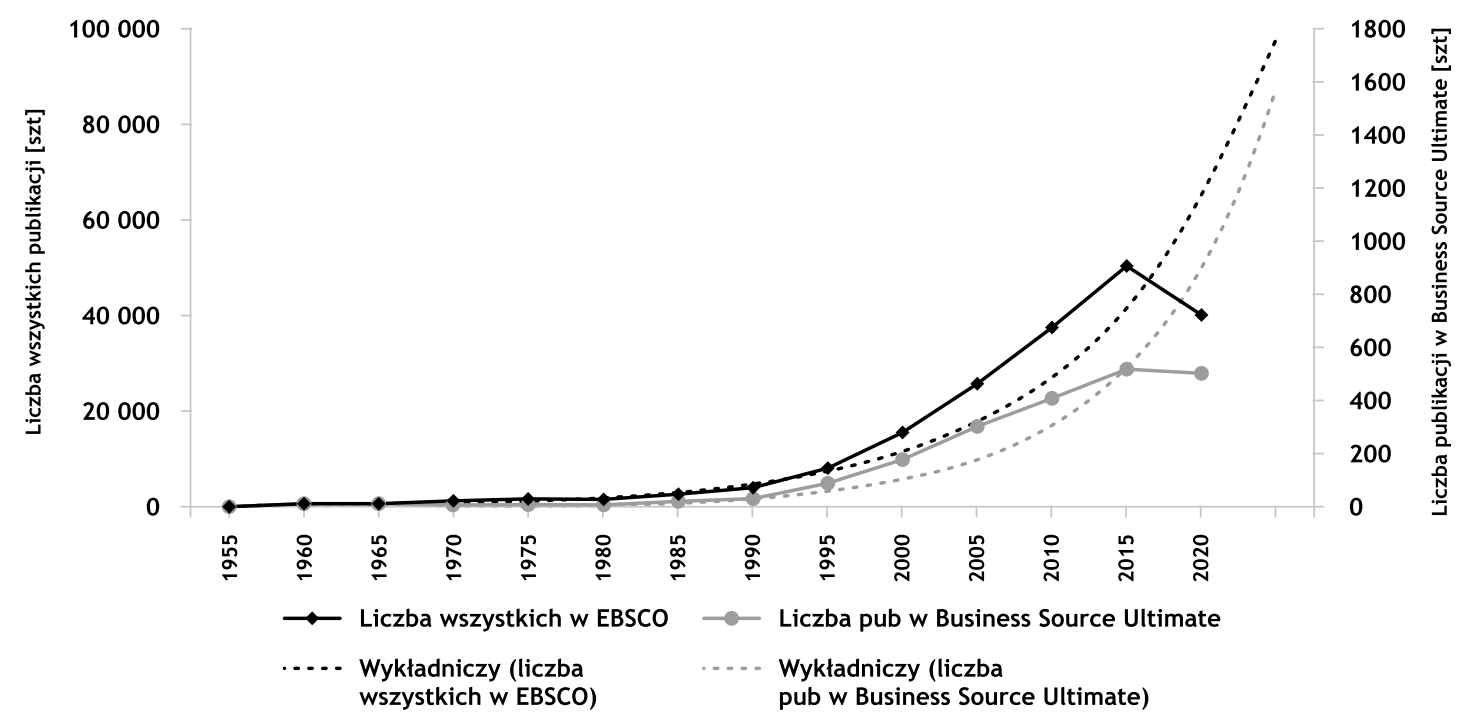

Niższa wartość dla roku 2020 jest wynikiem daty prowadzenia badań (rok 2020 dopiero się rozpocząt)

Rys. 1. Liczba publikacji ze stowem „opportunism” w bazie EBSCO oraz bazie danych Business Source Ultimate na dzień 10.01.2020 r.

Źródło: opracowanie wtasne

EBSCO Discovery Service (EDS) w nakładce oferowanej przez Bibliotekę Politechniki Łódzkiej. W wyszukiwarce podano słowo „opportunism”. Uzyskano w ten sposób w bazie EBSCO 188336 pozycji, a w bazie danych Business Source Ultimate - 2048 publikacji.

Jak widać na rysunku 1, popularność zjawiska „opportunism" w publikacjach zaindeksowanych w bazie EBSCO jest duża. Pierwsza publikacja ze słowem oportunizm w bazie pochodzi z 1893 roku (a ich liczność do 1950 r. była bardzo niewielka). Publikacje w bazie danych Business Source Ultimate stanowią tylko 1,09\% wszystkich publikacji bazy EBSCO (publikacje ze słowem „opportunism” $\mathrm{w}$ tytule stanowią 14,64\%). Liczba publikacji niezależnie od bazy danych wykazuje istotną wykładniczą tendencję wzrostową w kolejnych latach. W obu przypadkach w ponad 92\% zmiany w liczbach publikacji wyjaśnione są poprzez kolejne lata publikacji (zagregowane na rysunku $\mathrm{w}$ okresy pięcioletnie). Wyznaczona tendencja wykładnicza sugeruje wysoką stopę wzrostu, tzn. kolejny rok spowoduje przeciętnie przyrost poziomu liczby publikacji w bazie EBSCO o 10,72\%, a w bazie danych Business Source Ultimate o $14,87 \%$. Największy ich wzrost rozpoczyna się po latach 80 . Warto zaznaczyć, że wtedy pojawiła się publikacja G. Johna $(1984)^{4}$, która uznawana jest za kluczową w badaniach oportunizmu, ponieważ jako pierwsza proponowała narzędzia pomiaru tego zjawiska. Przyjmując, że ta wykładnicza tendencja rozwojowa zostanie zachowana (postawa optymistyczna prognosty wobec przyszłości oraz brak korekty prognostycznej dotyczącej liczebności publikacji w 2020 roku wskazywać będzie na równie intensywną eksplorację), to przewiduje się, że dla lat 2021-2025 w bazie EBSCO pojawią się 97122 nowe prace, a w bazie danych Business Source Ultimate - 1566 nowych prac $\mathrm{z}$ zakresu oportunizmu. Taka tendencja rozwojowa może wskazywać na dwa możliwe scenariusze przyszłości. Pierwszy polegający na dalszym rozwoju badań w zakresie oportunizmu, konwergencji badań, ich stosowalności $\mathrm{w}$ różnych obszarach organizacji i zarządzania. Zakłada się zatem, że oportunizm znajdzie zastosowanie $\mathrm{w}$ różnych koncepcjach teoretycznych i będzie podlegał dalszej intensywnej eksploracji. Druga wiąże się z możliwością spadku zainteresowania tym zjawiskiem ze względu na jego ograniczenia lub wyeksplorowanie (Kelly i in., 2018). Rozstrzygnięcie tej kwestii będzie możliwe dopiero w perspektywie kilku kolejnych lat.

Przyglądając się afiliacji przestrzennej autorów prac $\mathrm{w}$ bazie Business Source Ultimate (rys. 2), zauważono, że dominują reprezentanci kontynentu ${ }^{5}$ Ameryka - stanowią 41\% (z 92,68\% udziałem autorów z USA), na drugim miejscu są Azjaci - 27\% (z 67,09\% udziałem autorów z Chin), na trzecim miejscu (tylko $\mathrm{z}$ różnicą jednego punktu procentowego) autorzy z Europy (z 59,74\% udziałem autorów z Wielkiej Brytanii).

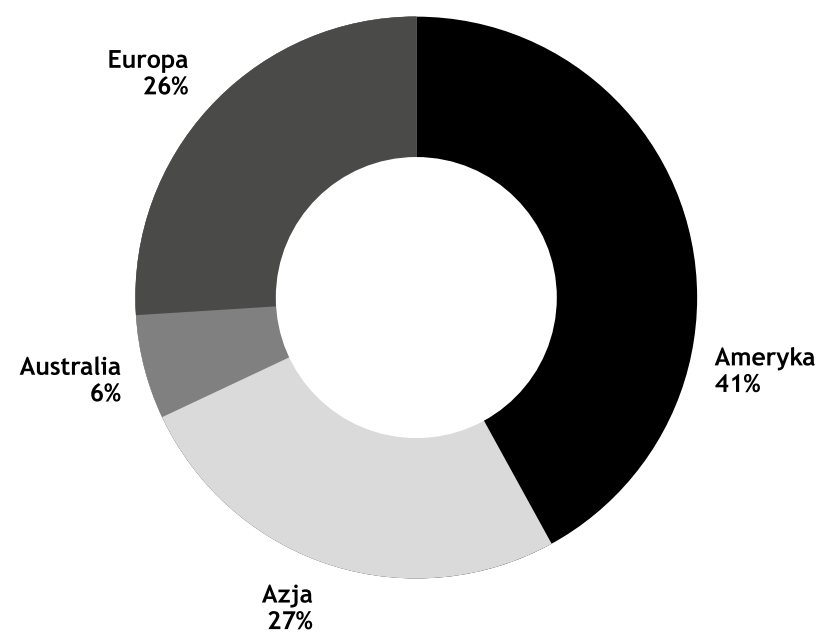

Rys. 2. Afiliacje autorów publikacji w bazie Business Source Ultimate ze stowem „opportunism” na dzień 10.10.2020 r.

Źródto: opracowanie wtasne 
Publikacje dotyczące oportunizmu w bazie EBSCO lub jej podbazie Business Source Ultimate należy uznać za powszechne. Ponad $40 \%$ prac jest autorstwa osób z kontynentu Ameryka.

Przejrzenie 2048 publikacji zgodnie z kluczem kategoryzacyjnym i przy niedostępnych specjalistycznych narzędziach analitycznych było poza możliwościami autorki. W związku z tym zdecydowano się na ograniczenie liczby publikacji. Podejścia do wyboru prac w przeglądzie literatury są bardzo zróżnicowane, np. w pracy S. Kelly i in. (2018) w systematycznym przeglądzie literatury wylistowano łącznie 1486 artykułów odnoszących się do zjawiska oportunizmu, korzystając z wyszukiwarek Google Scholar i Summon oraz z bazy danych: EBSCO Business Premier i Emerald oraz listy czasopism z zakresu zarządzania operacyjnego, marketingu i innych aspektów biznesu. W dalszym kroku autorzy przefiltrowali wyniki słowem dostawca i otrzymane 345 prac poddali badaniom jakościowym, mającym na celu przedstawienie szczegółowego podejścia do badania i pojęcia „opportunism”, ostatecznie w pracy zaprezentowali szczegółowe wyniki przeglądu 37 artykułów (które zostały wylistowane jako pierwsze). Zatem w celu przeprowadzenia badań jakościowych zdecydowano się na ograniczenie liczby publikacji poprzez wprowadzenie kolejnych oferowanych przez wyszukiwarkę EDS kryteriów selekcji. Zastosowane w kolejnych krokach kryteria doboru oraz pojawiające się liczby publikacji przedstawiono $\mathrm{w}$ tabeli 1 . Zatem do przedstawianych poniżej badań jakościowych wykorzystano znalezionych 205 prac (podobnie jak w pracach: Zakrzewska-Bielawska, 2016, Wójcik, Czernek, 2016).

\section{Definicje oportunizmu}

$\mathbf{Z}$ godnie z definicją O.E. Williamsona (1985, s. 161), oportunizm odnosi się do poszukiwania własnych korzyści poprzez zachowanie charakteryzujące się wysiłkami zmierzającymi do wprowadzenia w błąd lub zmylenia partnerów. W analizowanych pracach autorzy szukają wyjaśnienia oportunizmu na gruncie teorii kosz- tów transakcyjnych i teorii wymiany relacyjnej. W obu teoriach dominującym paradygmatem jest minimalizowanie kosztów wymiany, gdyż ze względu na niepewność i ryzyko zachowań oportunistycznych partnerów niektóre transakcje są wysoce kosztowne (Brown i in., 2000, s. 51). Zgodnie z podejściem O.E. Williamsona (1993, s. 98), podejrzenie oportunizmu w wymianie nigdy nie jest zerowe, jednak wartość tych podejrzeń jest względnie niska. Potwierdzają to również badania empiryczne przedstawione np. w pracach takich autorów, jak: G.T. Gundlach i in. (1995), R.S. Achrol i G.T. Gundlach (1999), J.R. Brown i in. (2000), D.I. Gilliland i K.C. Manning (2002), A.I. Rokkan i in. (2003), S.D. Jap i E. Anderson (2003), S. Wuyts i I. Geyskens (2005), J.B. Heide i in. (2007), S.D. Jap (2007), V. Kashyap i in. (2012), S.H. Seggie i in. (2013), T. Yan, T.J. Kull (2015). Ponadto w uwarunkowaniach teoretycznych zwraca się uwagę, że podejrzenie o oportunizm nie może być zbyt wysokie, bo strony nie dokonywałyby transakcji, a koszty zabezpieczeń byłby bardzo wysokie (You i in., 2018; Heide i in., 2007; Wuyts, Geyskens, 2005).

Jeżeli chodzi o definiowanie oportunizmu, to autorzy powołują się bezpośrednio na różne definicje O.E. Williamsona $(1979 ; 1985 ; 1996)$ lub pośrednio poprzez modyfikacje i ich ewolucje wskazują swoje (John, 1984; Anderson, 1988; Provan, Skinner, 1989; Gundlach i in., 1995; Dahlstrom, Nygaard, 1999; Brown i in., 2000; Wathne, Heide, 2000; Jap, Anderson, 2003; Luo, 2006; Heide i in., 2007; Lu i in., 2015; 2016). Wprowadzane modyfikacje nie stanowią jednak widocznych różnic w postrzeganiu tego zjawiska. Szczegółowy przegląd definicji oportunizmu przedstawianych w zakresie relacji dostawca-klient oraz ich uwarunkowań empirycznych w pracy S. Kelly i in. (2018) wskazuje, iż badania empiryczne oportunizmu niekoniecznie potwierdzają jego uwarunkowania teoretyczne.

\section{Prezentowane rodzaje oportunizmu}

W literaturze ze względu na uwarunkowania teoretyczne można spotkać wiele różnych klasyfikacji lub wyróżnianych rodzajów oportunizmu. Przyjmowane

Tabela 1. Kryteria wyszukiwania

\begin{tabular}{|l|c|c|}
\hline \multicolumn{1}{|c|}{ Kryteria doboru } & Liczba publikacji & Liczba publikacji \\
\hline \multicolumn{1}{|c|}{ Baza danych } & EBSCO & Business Source Ultimate \\
\hline Wyszukiwana fraza „opportunism” & 188336 & 1729 \\
\hline Dostęp: Pełen tekst & 108331 & 1329 \\
\hline Typ publikacji: Czasopisma naukowe & 61279 & 1233 \\
\hline Język publikacji: język angielski & 60194 & 416 \\
\hline Słowo w tytule & 2841 & 205 \\
\hline $\begin{array}{l}\text { Wykluczenie duplikatów oraz braku } \\
\text { dostępnósi }\end{array}$ & n.a. & 2048 \\
\hline
\end{tabular}

n.a. - oznacza, że nie analizowano tego zbioru

Źródło: opracowanie własne 
Tabela 2. Rodzaje oportunizmu

\begin{tabular}{|c|c|c|c|}
\hline $\begin{array}{c}\text { Kryteria } \\
\text { klasyfikacji }\end{array}$ & $\begin{array}{l}\text { Wskazywane } \\
\text { rodzaje }\end{array}$ & Definicje & Źródło \\
\hline \multirow{2}{*}{ Czas } & ex ante & $\begin{array}{l}\text { czy i na ile celowo dochodzi do wprowadzenia w błąd na } \\
\text { początkowych etapach relacji, wiąże się on z większymi } \\
\text { kosztami tworzenia obszernych kontraktów mających na } \\
\text { celu ograniczenie przebiegłych zachowań stron }\end{array}$ & \multirow{2}{*}{$\begin{array}{l}\text { O.E. Williamson } \\
(1985, \text { s. 126), } \\
\text { J.R. Brown i in. } \\
\text { (2000, s. 54), } \\
\text { J.B. Heide i in. } \\
\text { (2007, s. 431), } \\
\text { S.H. Seggie i in. } \\
(2013)\end{array}$} \\
\hline & expost & $\begin{array}{l}\text { czy i na ile dochodzi do naruszenia relacji w bardziej } \\
\text { zaawansowanych jej stadiach, powoduje dodatkowe } \\
\text { koszty transakcyjne w postaci monitoringu, kontroli czy } \\
\text { modyfikowania i egzekwowania warunków umowy }\end{array}$ & \\
\hline \multirow[t]{2}{*}{$\begin{array}{l}\text { Siła oddziaływania } \\
\text { skutków }\end{array}$} & silny & $\begin{array}{l}\text { forma obejmująca działania, które naruszają normy } \\
\text { umowne (warunki, klauzule itp.), np. kradzież wspólnego } \\
\text { majątku; wywłaszczenie wiedzy lub technologii; } \\
\text { przywłaszczenie kluczowego personelu, unikanie } \\
\text { zobowiązań umownych }\end{array}$ & \multirow{2}{*}{$\begin{array}{l}\text { Y. Luo (2006), } \\
\text { V. Kashyap i in. } \\
(2012 \text {, s. 260-272) }\end{array}$} \\
\hline & slaby & $\begin{array}{l}\text { forma obejmująca działania, które naruszają normy } \\
\text { relacyjne, w konsekwencji pogarszając sytuację jednej ze } \\
\text { stron }\end{array}$ & \\
\hline \multirow{2}{*}{ Formalizacja } & jawny & $\begin{array}{l}\text { strona relacji uchyla się od zobowiązań wynikających } \\
\text { z umowy formalnej }\end{array}$ & \multirow{2}{*}{$\begin{array}{l}\text { B.R. Barnes i in. } \\
\text { (2010, s. 37), } \\
\text { D.I. Gilliland } \\
\text { i K.C. Manning } \\
\text { (2002) }\end{array}$} \\
\hline & $\begin{array}{l}\text { niejawny } \\
\text { (ukryty) }\end{array}$ & strona narusza zasady umów społecznych & \\
\hline \multirow[b]{2}{*}{ Intencje strony } & $\begin{array}{l}\text { nadmierny } \\
\text { oportunizm }\end{array}$ & $\begin{array}{l}\text { określany jako otwarta pogoń za zyskiem lub korzyścią } \\
\text { jednej ze stron na rzecz wymiany kosztem partnera, np. } \\
\text { dostawca wymusza podwyżkę cen bez przedstawienia } \\
\text { jakiegokolwiek uzasadnienia }\end{array}$ & \multirow{2}{*}{$\begin{array}{l}\text { S. Kelly i in. } \\
(2018)\end{array}$} \\
\hline & $\begin{array}{l}\text { oportunizm } \\
\text { z przebiegłością }\end{array}$ & $\begin{array}{l}\text { ukryte dążenie do korzyści z zamierzoną intencją } \\
\text { oszukiwania przez jedną ze stron transakcji, np. dostawca } \\
\text { żąda podwyżki cen, powołując się w uzasadnieniu } \\
\text { na umyślnie zniekształcone dane i ukrywa ich } \\
\text { zniekształcenie }\end{array}$ & \\
\hline \multirow[t]{2}{*}{ Aktywność strony } & $\begin{array}{l}\text { czynny } \\
\text { (aktywny) }\end{array}$ & $\begin{array}{l}\text { strona relacji celowo powstrzymuje swoje działania, } \\
\text { dochodzi do oportunizmu poprzez: kłamstwo, } \\
\text { przeinaczanie, czy fałszowanie faktów, wyolbrzymianie } \\
\text { trudności i wykorzystywanie nieoczekiwanych zdarzeń } \\
\text { do pozyskiwania ustępstw od drugiej strony }\end{array}$ & \multirow[t]{2}{*}{$\begin{array}{l}\text { K.H. Wathne } \\
\text { i J.B. Heide (2000) }\end{array}$} \\
\hline & $\begin{array}{l}\text { bierny } \\
\text { (pasywny) }\end{array}$ & $\begin{array}{l}\text { polegający na tym, że podejmowane są pewne działania } \\
\text { określone w umowie jako zabronione lub etycznie } \\
\text { niepoprawne }\end{array}$ & \\
\hline
\end{tabular}

Źródto: opracowanie wtasne

kryteria klasyfikacji to: czas, siła oddziaływania, formalizacja, intencje strony, aktywność strony (tab. 2).

W pracach empirycznych podejmowane są badania oportunizmu ex post. Badania empiryczne dotyczące oportunizmu ex ante są rzadkością. Z praktycznego punktu widzenia te rodzaje oportunizmu pozwalają wskazać mechanizmy zarządzania ex ante, które należy wzmacniać lub które ex post należy wyhamowywać, np. w swoich badaniach J.R. Brown i in. (2000, s. 54) oraz J.B. Heide i in. (2007, s. 431) wskazują, że monitorowanie wyników i zachowowań znacznie łagodzi relacje oportunistyczne. W analizowanych pracach jako oportunizm słaby wskazywane są: przedterminowe zakończenie zobowiązania lub niezrealizowanie obietnic; łamanie zasady wzajemnej wyrozumiałości czy zasady dzielenia się wiedzą; ukrywanie krytycznych zasobów; fałszywe przedstawianie informacji i manipulowanie nimi, nieuczciwe reagowanie na renegocjacje umowne lub zmiany; podejmowanie wysiłków w celu wprowadzenia w błąd. W niektórych pracach kategorie oportunizmu jawnego $i$ silnego oraz niejawnego $i$ słabego traktowane są jako równoważne.

W analizowanych pracach są opisy rodzajów oportunizmu, natomiast w części empirycznej nie ma kategoryzacji i są one badane łącznie. Z kolei J.R. Brown i in. (2000); S.D. Jap i E. Anderson (2003); K.H. Wathne i J.B. Heide (2000) podkreślają, że oportunizm jest synonimem wprowadzenia w błąd, oszustwa, niewłaściwych zachowań, takich jak selekcja negatywna, pokusy nadużycia, bumelowanie itp. Zatem jest tu 
wyraźny nacisk na jego niejawna formę. S. Kelly i in. (2018) oportunizm prezentowany w pracy K.H. Wathne i J.B. Heide (2000) kwalifikują jako nadmierny. Potencjał skuteczności egzekwowania przepisów, czyli zasady compliance (zapewnienie zgodności działalności z regulacjami prawnymi, normami bądź zestawami zaleceń), w badaniach jest różnie traktowany, czasami pojawia się on jako oddzielna zmienna ukryta (takie stanowisko prezentują w swoich badaniach D.I. Gilliland i K.C. Manning (2002) oraz V. Kashyap i in. (2012, s. 260-272)), a czasami stanowi pytanie lub zestaw pytań w ramach konstruktu oportunizm.

Raczej we wszystkich prezentowanych pracach dominuje nadmierny oportunizm, bo ten z przebiegłościa jest trudny do udowodnienia i jak samoistnie nie wyjdzie na jaw, to strona nie jest o nim poinformowana. W literaturze brak pozycji opisujących takie przypadki.

Mimo że K.H. Wathne i J.B. Heide (2000) przedstawiają swoją klasyfikację oportunizmu z uwzględnieniem wielu aspektów, to i tak w badaniach empirycznych przyjmują jeden ogólny konstrukt. Wyjątkiem jest praca S.H. Seggie i in. (2013), w której wyróżniono w części empirycznej aktywny i pasywny oportunizm. Z badań S.H. Seggie i in. (2013) wynika, ze firmy tolerują bardziej pasywny niż aktywny oportunizm, a koszty transakcyjne pełnią rolę pośredniczącą między formą oportunizmu a satysfakcją $\mathrm{z}$ relacji. Badanie to pokazuje, że z czasem pasywny oportunizm ma bardziej erozyjny wpływ na zadowolenie z wyników niż aktywny oportunizm. S.H. Seggie i in. (2013) pokazują, że rozróżnienie biernego i aktywnego oportunizmu pozwala na lepsze zrozumienie konsekwencji oportunizmu oraz inne podejście do zarządzania nim.

W badaniach empirycznych (wyjątek stanowią D.I. Gilliland i K.C. Manning (2002), V. Kashyap i in. (2012) oraz S.H. Seggie i in. (2013)), nie ma przedstawionych różnych rodzajów oportunizmu, oportunizm badany jest jako całość (jeden wielowymiarowy konstrukt). Stąd też rozbieżności wskazane w pracy S. Kelly i in. (2018) definicji oportunizmu w ujęciu teoretycznym, a jej egzemplifikacji empirycznej. Uwzględniając oportunizm, zamiast konkretne jego rodzaje, wiele interesujących problemów organizacji może zostać pominiętych lub błędnie zinterpretowanych (Kelly i in., 2018; Seggie i in., 2013). Zatem za nisze należy uznać prowadzenie badań empirycznych z uwzględnieniem różnych rodzajów oportunizmu przedstawionych w tabeli 2 .

\section{Podejścia stosowane w empirycznych badaniach oportunizmu}

$\mathbf{K}^{2}$ ategoryzacja artykułów wskazuje, że są to prace koncepcyjne, teoretyczne, empiryczne, oraz prace przeglądowe (tych jest bardzo mało). Można w nich wyróżnić opracowania dotyczące praktyk, modeli i procesów związanych z zachowaniami oportunistycznymi (Wuyts, Geyskens, 2005; Heide i in., 2007; Lu i in., 2016; Lianying, Qinzhen, 2017) oraz czynników kontekstualnych warunkujących oportunizm (Seggie i in., 2013; Crosno, Dahlstrom, 2016).
W literaturze zidentyfikowano $\mathrm{w}$ badaniach empirycznych następujące podejścia:

- zbieranie informacji na temat oportunizmu respondenta (Brown i in., 2000; Wuyts, Geyskens, 2005; Heide i in., 2007; Lu i in., 2016; Lianying, Qinzhen 2017),

- zbieranie informacji na temat oportunizmu przeciwnej strony (John, 1984; Dahlstrom, Nygaard, 1999; Gilliland, Manning, 2002; Rokkan i in., 2003; Jap, 2007; Kashyap i in., 2012; Seggie i in., 2013; Crosno, Dahlstrom, 2016; Lianying, Qinzhen, 2017; Zhang i in., 2017; Um, Kim, 2018; Verbeke i in., 2018; Yan, Kull, 2015; You i in., 2018),

- zbieranie informacji na temat oportunizmu obu z badanych stron (Achrol, Gundlach, 1999; Gundlach i in., 1995; Rokkan i in., 2003; Jap, Anderson, 2003).

Zidentyfikowano też podejście S.D. Jap i E. Andersona (2003) jako mieszane, bo w nim kupujący i dostawca oceniają strony i swoje oportunistyczne zachowanie ex post $\mathrm{w}$ procesie wymiany.

Badania empiryczne są prowadzone jako badania ilościowe, a narzędzie pomiaru jest oparte na skali Likerta: 7-puktowej (Yan, Kull, 2015) lub 5-punktowej (John, 1984).

Analizowane prace wskazują, że zachowania oportunistyczne pojawiają się w wyniku różnic w celach (Rokkan i in., 2003), w postrzeganiu istotności informacji (Crosno, Dahlstrom, 2016), preferencjach dotyczacych ryzyka stron (Lianying, Qinzhen, 2017), formalizacji (Dahlstrom, Nygaard, 1999; Jap, 2007). Wyniki przedstawionych badań empirycznych wykazują, że działania monitorujące znacząco wpływają na zachowania partnerów (Dahlstrom, Nygaard, 1999). Powszechny w badaniach jest nurt wskazywania oportunizmu jako efektu (John, 1984; Dahlstrom, Nygaard, 1999; Lianying, Qinzhen, 2017; Um, Kim, 2018)). Prace dotyczące poszukiwań ancendencji oportunizmu nie występują.

$\mathrm{Z}$ badań empirycznych prezentowanych $\mathrm{w}$ tych pracach wynika, że zachowania oportunistyczne mogą wystąpić w różnych okolicznościach. Są jednak zdiagnozowane warunki ułatwiające ich pojawienie się. Należą do nich między innymi: asymetria informacji dotyczących atrybutów stron (Heide i in., 2007), niepewność partnera (You i in., 2018), odległe rynki (Verbeke i in., 2019), kontekst realizowanych zadań i celów (Crosno, Dahlstrom, 2016), rodzaj relacji (Brown i in., 2000; Rokkan i in., 2003). Wskazywanym środkiem zaradczym jest monitoring, odpowiedni dobór partnerów, podobieństwo wartości i norm, bodźce motywacyjne zachęcające do dotrzymania warunków umowy i zniechęcające do ich łamania (Gilliland, Manning, 2002).

\section{Podsumowanie}

D odejmując próbę syntezy aktywności badawczej w zakresie oportunizmu, można stwierdzić, że liczba pozycji $z$ tego zakresu oraz ich wzrostowa tendencja wykładnicza może wskazywać na wyeksplorowanie 
zjawiska oportunizmu. Jednak późniejsza analiza jakościowa wykazała na wiele luk poznawczych. Ograniczeniem zainteresowania tym zjawiskiem w przyszłości może być wskazywana w wielu pracach niska częstotliwość tego zjawiska lub niski jego wpływ na deklarowany w badaniach cel. Pozytywnym aspektem pozwalającym na prowadzenie badań empirycznych jest wypracowanie skal pomiaru oportunizmu. Jednym z niszowych nurtów badawczych jest uwzględnianie w badaniach empirycznych konkretnych rodzajów oportunizmu, wskazywanych w pracach teoretycznych i koncepcyjnych. Dzięki temu podejściu może udać się wyjaśnić wiele interesujących problemów organizacji do tej pory pomijanych lub błędnie interpretowanych. Badania oportunizmu skupiają się na percepcji respondenta, a nie faktycznych zachowaniach czy bezpośrednio mierzalnych zjawiskach. Zatem ważnym aspektem przyszłych badań są opisy przypadków oportunistycznych zachowań powodujących katastrofalne problemy przynajmniej dla jednej ze stron relacji i próba zmiany podmiotu badania. Drugim nurtem niszowym są wielopoziomowe badania dotyczące par zależnych w konkretnych relacjach, np. na poziomie diad czy sieci. Trzecim wyzwaniem jest brak badań i rozważań koncepcyjnych uwzględniających metodyki adaptacyjne organizacji, dzielnie się wiedzą, przywództwo czy nowe koncepcje strategiczne (np. ambidexterity). Istniejąca wiedza w zakresie antecedencji oportunizmu jest niewystarczająca, gdyż nadal brak informacji, co stanowi asumpt do podjęcia zachowań oportunistycznych. Ponadto aktualny stan wiedzy w zakresie oportunizmu wymaga usystematyzowania i doprecyzowania celem uzyskania większej przejrzystości osiągnięć z tego zakresu - wykazano niewielką liczbę prac przeglądowych $\mathrm{z}$ tego zakresu.

Ograniczeniem prowadzonych badań jest wybór analizowanych prac, jakościowe podejście do opisu analizowanych treści i subiektywne przyporządkowanie do danej kategorii (według zdefiniowanych kluczy kategoryzacyjnych) lub prezentowanych zagregowanych treści. Największym jednak ograniczeniem prowadzonych badań jest niewykorzystanie technik grupowania, klasyfikacji i mapowania informacji zawartych $\mathrm{w}$ prezentowanych pracach.

\section{dr inż. Iwona Staniec \\ Politechnika Łódzka \\ Wydział Zarządzania i Inżynierii Produkcji \\ ORCID: 0000-0002-5580-5450 \\ e-mail: iwona.staniec@p.lodz.pl}

\section{Przypisy}

1) Badania bibliometryczne swój rozwój zawdzięczają założeniu w 1963 roku Science Citation Index, rejestru publikacji naukowych i zawartych w nich cytatów oraz postępowi technologicznemu w zakresie dostępu do publikacji naukowych, a także narzędzi pozwalających na ich analizę.
2) Najważniejsze właściwości wyszukiwarki EDS to: możliwość wyszukiwania po tytułach czasopism, książek i publikacji, opcja wyszukiwania według wybranych baz danych, opcja zawężania i rozszerzania rezultatów wyszukiwania według różnych kryteriów, np. pełny tekst, publikacje recenzowane naukowo, zakres chronologiczny, wyświetlanie powiązanych rezultatów wyszukiwań.

3) Takie techniki wykorzystano w pracy J. Ejdys (2016, s. 41-43).

4) Ma ona w bazie Web of Science na dzień 10.01.2020 r. 466 cytowań (liczba wskazuje na tendencję wzrostową) i jest na czwartym miejscu w rankingu najczęściej cytowanych prac tego autora.

5) Autorka sama zadecydowała o kategoryzacji według kontynentów, bo wskazywana przez przeglądarkę nie posiadała rozłącznego klucza w układzie krajów.

\section{Bibliografia}

[1] Achrol R.S., Gundlach G.T. (1999), Legal and Social Safeguards Against Opportunism in Exchange, „Journal of Retailing", Vol. 75, No. 1, pp. 107-124.

[2] Anderson E. (1988), Transaction Costs as Determinants of Opportunism in Integrated and Independent Sales Forces, „Journal of Economic Behavior and Organization”, No. 9, pp. 247-264.

[3] Barnes B.R., Leonidou L.C., Siu N.Y.M., Leonidou C.N. (2010), Opportunism as the Inhibiting Trigger for Developing Long-term-oriented Western Exporter-Hong Kong Importer Relationships, „Journal of International Marketing", Vol. 18, pp. 35-63.

[4] Brown J.R., Dev C.S., Lee D.J. (2000), Managing Marketing Channel Opportunism: The Efficacy of Alternative Governance Mechanisms, „Journal of Marketing”, No. 64, pp. 51-65.

[5] Crosno J.L., Dahlstrom R.F. (2016), An Empirical Investigation of Bilateral Investments and Opportunism in Buyer-Supplier Relationships, „Journal of Marketing Channels", No. 23, pp. 146-156.

[6] Czakon W. (2005), Istota relacji sieciowych przedsiębiorstwa, „Przegląd Organizacji”, Nr 9, s. 10-13.

[7] Czakon W. (2011), Metodyka systematycznego przegladu literatury, „Przegląd Organizacji”, Nr 3, s. 57-61.

[8] Dahlstrom R., Nygaard A. (1999), An Empirical Investigation of Ex post Transaction Costs in Franchised Distribution Channels, "Journal of Marketing Research", No. 36, pp. 160-170.

[9] Ejdys J. (2016), Problematyka społecznej odpowiedzialności biznesu jako obiekt naukowych zainteresowań - wyniki analizy bibliometrycznej, „Przegląd Organizacji”, Nr 4, s. 36-44.

[10] Gilliland D.I., Manning K.C. (2002), When Do Firms Conform to Regulatory Control? The Effect of Control Processes on Compliance and Opportunism, "Journal of Public Policy \& Marketing”, No. 21, pp. 319-331.

[11] Gundlach G.T., Achrol R.S., Mentzer J.T. (1995), The Structure of Commitment in Exchange, „Journal of Marketing", No. 59, pp. 78-92.

[12] Heide J.B., Wathne K.H., Rokkan A.I. (2007), Interfirm Monitoring, Social Contracts, and Relationship Outcomes, „Journal of Marketing Research”, Vol. 44, No. 3, pp. 425-433. 
[13] Jap D.S., Anderson E. (2003). Safeguarding Interorganizational Performance and Continuity under Ex Post Opportunism, „Management Science”, Vol. 49, No. 12, pp. 1684-1701.

[14] Jap S.D. (2007), The Impact of Online Reverse Auction Design on Buyer-Supplier Relationships, „Journal of Marketing", No. 71, pp. 146-159.

[15] John G. (1984), An Empirical Investigation of Some Antecedents of Opportunism in a Marketing Channel, „Journal of Marketing Research”, Vol. 21, No. 3, pp. 278-289.

[16] Kashyap V., Antia K.D., Frazier G.L. (2012). Contracts, Extra Contractual Incentives, and Ex Post Behavior in Franchise Channel Relationships. „Journal of Marketing Research", Vol. 49, No. 2, pp. 260-276.

[17] Kelly S., Wagner B., Ramsay J. (2018), Opportunism in Buyer-supplier Exchange: A Critical Examination of the Concept and its Implications for Theory and Practice Production Planning \& Control, „The Management of Operations", Vol. 29, No. 12, pp. 992-1009.

[18] Lianying Z., Qinzhen Q. (2017), How Mediated Power Affects Opportunism in Owner-contractor Relationships: The Role of Risk Perceptions, „International Journal of Project Management", Vol. 35, No. 3, pp. 516-529.

[19] Lu P., Qian L., Chu Z., Xu X. (2015), Role of Opportunism and Trust in Construction Projects: Empirical Evidence from China, ,Journal of Management Engineering”, No. 32(2), pp. 1-10.

[20] Lu W., Zhang L., Zhang L. (2016), Effect of Contract Completeness on Contractors' Opportunistic Behavior and the Moderating Role of Interdependence, „Journal Construction Engineering Management", Vol. 142, No. 6.

[21] Luo Y. (2006), Opportunism in Interfirm Exchange in Emerging Markets, „Management \& Organization Review", Vol. 2, No. 1, pp. 121-147.

[22] Provan K.G., Skinner S.J. (1989), Interorganizational Dependence and Control as Predictors of Opportunism in Dealer-Seller Relations, „Academy of Management Journal", No. 32, pp. 202-212.

[23] Ratajczak-Mrozek M., Zieliński M. (2013), Czynniki usieciowienia przedsiębiorstw-ujęcie koncepcyjne, „Przegląd Organizacji”, Nr 11, s. 32-37.

[24] Rokkan A.I., Heide J.B., Wathne K.H. (2003), Specific Investments in Marketing Relationships: Expropriation and Bonding Effects, "Journal of Marketing Research", No. 40 , pp. $210-224$.

[25] Seggie S.H., Griffith D.A., Jap S.D. (2013), Passive and Active Opportunism in Interorganizational Exchange, „Journal of Marketing”, Vol. 77, No. 6, pp. 73-90.

[26] Um K.H., Kim S.M. (2018), Collaboration and Opportunism as Mediators of the Relationship between NPD Project Uncertainty and NPD Project Performance, „International Journal of Project Management", Vol. 36, No. 4, pp. 659-672.

[27] Verbeke A., Ciravegnad L., Lopeze L.E., Kunduf S.K. (2019), Five Configurations of Opportunism in International, Market Entry, "Journal of Management Studies”, Vol. 56, No. 7, pp. 1287-1313.

[28] Wathne K.H., Heide J.B. (2000), Opportunism in Interfirm Relationships: Forms. Outcomes, and Solutions, „Journal of Marketing", No. 64, pp. 36-51.
[29] Williamson O.E. (1979), Transaction Costs Economics: The Governance of Contractual Relationships, „Journal of Law and Economics", No. 22, pp. 223-260.

[30] Williamson O.E. (1985), The Economic Institutions of Capitalism, The Free Press, New York.

[31] Williamson O.E. (1993), Opportunism and Its Critics, „Managerial and Decision Economics”, Vol. 14, No. 2, pp. 97-107.

[32] Williamson O.E. (1996), The Mechanisms of Governance, Oxford University Press, New York.

[33] Wójcik D., Czernek K. (2016), Antecedencje współpracy przedsiębiorstw $w$ sektorze turystycznym - wyzwania badawcze, Prace Naukowe Uniwersytetu Ekonomicznego we Wrocławiu, Nr 421, s. 632-644.

[34] Wuyts S., Geyskens I. (2005), The Formation of BuyerSupplier Relationships: Detailed Contract Drafting and Close Partner Selection, „Journal of Marketing”, No. 69, pp. 103-117.

[35] Yan T., Kull T.J. (2015), Supplier Opportunism in Buyer-Supplier New Product Development: A China U.S. Study of Antecedents, Consequences, and Cultural/Institutional Contexts, „Decision Sciences”, Vol. 46, No. 2, pp. 403-444.

[36] You J., Chen Y., Wang W., Shi Ch. (2018), Uncertainty, Opportunistic Behavior, and Governance in Construction Projects: The Efficacy of Contracts, „International Journal of Project Management", No. 36, pp. 795-807.

[37] Zakrzewska-Bielawska A. (2016), Ambidexterity - światowe trendy eksploracji w naukach o zarządzaniu, „Przegląd Organizacji”, Nr 1, s. 16-23.

[38] Zhang C., Li J., Huang Y. (2017), Sustaining Relationships after Opportunism and Misunderstanding: the Role of Formalization and Socialization, „Marketing Letters”, Vol. 28, No. 2, pp. 305-319.

\section{Opportunism - Exploration Trends in Scientific Paper}

\section{Summary}

The paper is a review of literature on opportunism in the context of management. The aim of the presented study is to identify exploration trends related to opportunism with the use of a literature review. The research utilised a quantitative and qualitative approach. Categorisation has been conducted according to the following criteria: definitions of opportunism, types of opportunism, types of scientific papers, subjects and subjects of research, contextual factors. The review of literature has identified research gaps or niche research trends. The number of publications in this area indicates a significant growing tendency, which may indicate a further increase in the number of these publications or a decrease in interested resulting from the exhaustion of the explored subject area.

\section{Keywords}

opportunism, research trends, types of opportunism 